\title{
Clinical evaluation of unadapted sheep submited to sudden intake of melon with high levels of sugar
}

\author{
Avaliação clínica de ovinos não adaptados submetidos à ingestão \\ súbita de melão com alto teor de açúcar
}

\author{
Francisco Leonardo Costa Oliveira' ${ }^{1}$; Raimundo Alves Barrêto Júnior ${ }^{2}$; Antonio \\ Humberto Hamad Minervino ${ }^{3}$; Leonardo Frasson Reis ${ }^{1}$; Marcondes Dias Tavares ${ }^{4}$; \\ Rodolfo Gurgel Vale ${ }^{4}$; Jucélio Silva Gameleira ${ }^{4}$; Francisco Jocelho Alexandre \\ Souza $^{5}$; Clara Satsuki Mori ${ }^{6}$; Enrico Lippi Ortolani ${ }^{7 *}$
}

\begin{abstract}
This study evaluated the clinical effects of two different amounts of melon, with a high sugar content, suddenly offered to unadapted sheep. Twelve rumem cannulated crossbred 8-months-old sheep , weighing $25 \mathrm{~kg}$ each, were used. These sheep had never been fed with food concentrated with sugar or fruits. The animals were kept in collective pens with a basal diet of roughage and then randomly divided into two equal groups. The sheep in the two groups received $25 \%$ and $75 \%$ of dry matter (DM) of the diet the crushed melon, administered by the rumen cannula. Physical examination and measurement of rumen fluid $\mathrm{pH}$ was performed at the following times: $0,3,6,12,18$ and $24 \mathrm{~h}$. The animals of $\mathrm{G} 25 \%$ did not present clinical signs despite subacute acidosis expected after administration of the melon. However, in the G75\%, sheep developed clinical manifestation indicative of lactic acidosis with rumen fluid $\mathrm{pH}$ lower than 5.0 from T6h, but did not present with dehydration. In sheep from G75\%, tachycardia was observed at $3 \mathrm{~h}$ and continued until the end of the study; tachypnea was also observed at $3 \mathrm{~h}$, which was caused by increased abdominal circumference. Based on the results obtained, the supplementation of high amounts of melon (75\% DM) in the diet is not recommended for sheep, although the use of $25 \% \mathrm{DM}$ is safe. However, greater amounts of this fruit could be used in the diet of sheep with gradual adaptation to the substrate.
\end{abstract}

Key words: Acidosis, supplementation, fruits, $\mathrm{pH}$, rumen

\section{Resumo}

No presente trabalho estudaram-se os efeitos de duas quantidades diferentes de melão com alto teor de açúcares, oferecidas subitamente a ovinos não adaptados, sobre algumas variáveis clínicas. Foram

\footnotetext{
1 Médicos Veterinários, Discentes do Programa de Pós-Graduação em Clínica Veterinária da Faculdade de Medicina Veterinária e Zootecnia, FMVZ/ USP, São Paulo, SP, Brasil. E-mail: oliveiraflc@usp.br; leofrasson@gmail.com

2 Médico Veterinário, Prof. Dr., Dept ${ }^{\circ}$ de Ciência Animal, Universidade Federal Rural do Semiárido, UFERSA, Mossoró, RN, Brasil. E-mail: rbarreto@ufersa.edu.br

3 Médico Veterinário, Prof. Dr., Instituto de Biodiversidade e Floresta, Universidade Federal do Oeste do Pará, UFOPA, Santarém, PA, Brasil. E-mail: ah.minervino@gmail.com

4 Médicos Veterinários, Discentes do Programa de Pós-Graduação, Dept ${ }^{\circ}$ de Ciência Animal, Universidade Federal Rural do Semiárido, UFERSA, Mossoró, RN, Brasil. E-mail: marcondesmv@hotmail.com; rodolfo_g_vale@hotmail.com; jucelio_ gameleira@hotmail.com

5 Discente de Graduação do curso de Zootecnia, UFERSA, Mossoró, RN, Brasil. E-mail: jocelhosouza@hotmail.com

${ }^{6}$ Química, Técnica Nível Superior, FMVZ/USP, São Paulo, SP. Brasil. E-mail: clarasat@usp.br

7 Médico Veterinário, Prof. Titular, FMVZ/USP, São Paulo, SP. Brasil. E-mail: ortolani@usp.br

* Author for correspondence
} 
utilizados 12 ovinos canulados, mestiços da raça Santa Inês, machos, pesando $25 \mathrm{~kg}$, com oito meses de idade e que nunca haviam recebido rações concentradas, frutas ou raízes. Os animais foram mantidos em baias coletivas com dieta basal composta de volumoso e distribuídos aleatoriamente em dois grupos iguais que receberam, subitamente, quantidades de melão triturado correspondentes a 25 e $75 \%$ da matéria seca (MS) da dieta, administradas pela cânula ruminal. Foi realizado exame físico e mensuração do $\mathrm{pH}$ do fluido ruminal nos seguintes momentos: zero, 3, 6, 12, 18 e $24 \mathrm{~h}$. Os animais do G25\% não manifestaram sintomatologia clínica, apesar da acidose subaguda esperada após a administração de melão. Os animais do G75\% desenvolveram quadro clínico indicativo de acidose láctica ruminal, com $\mathrm{pH}$ deste fluido inferior a 5,0 a partir do T6h, mas sem apresentar desidratação. Nos ovinos do G75\% foi observada taquicardia a partir do momento 3 horas até o final do estudo e discreta taquipnéia no momento 3 horas, causadas pelo aumento da circunferência abdominal. Não se recomenda o oferecimento de altas quantidades de melão ( $75 \%$ da M.S.), porém a quantidade correspondente a $25 \%$ da M.S. é segura. Maiores concentrações dessa fruta na dieta podem ser utilizadas desde que se tomem cuidados para a adaptação gradual dos animais ao substrato.

Palavras-chave: Acidose, suplementação, frutas, $\mathrm{pH}$, rúmen

\section{Introduction}

The sheep industry is of great importance in the northeast region of Brazil. It is characterized by extensive farming systems with herds dominated by mongrel animals and low genetic potential, which reduces the production rates. Because of climatic factors that directly affect food availability throughout the year, intensive production systems are presented as alternatives to minimize this problem in the region (RODRIGUES et al., 2003).

Intensive production systems such as confinement and semi-confinement have been adopted by Brazilian ranchers to enjoy a greater slaughter rate and better quality of meat production, and to obtain better prices (BARRÊTO JÚNIOR et al., 2008). This intensification is gaining importance in the sheep industry because it is a control measure of haemonchosis, a very important parasitic disease that causes considerable economic losses (MINERVINO et al., 2014a; ORTOLANI et al., 2013).

Despite the aforementioned advantages, intensive systems entail higher production costs, especially costs resulting from food. The use of agroindustry byproducts is an alternative to increase profitability. In this context, the use of fruit waste is an option because fruits are produced in large quantities in all regions of Brazil (MINERVINO et al., 2014b). The melon is notable among different fruits because it is produced continuously and in large-scale in the country's northeastern region (which also accounts for more than one-half of Brazil's sheep herds); many fruits do not attain sale classification and are discarded (BARRÊTO JÚNIOR et al., 2008; LIMA et al., 2011; LOUSADA JÚNIOR et al., 2005).

Accompanying the intensification of the farming system is an increased incidence of disorders of nutritional and metabolic origin, especially ruminal lactic acidosis (NAGARAJA; LECHTENBERG, 2007). This disease results from an excessive intake of soluble carbohydrates, especially in nonadapted animals, and it may manifest as acute ruminal lactic acidosis (ARLA); subacute ruminal acidosis (SARA), or it may be chronic (BRAUN et al., 1992; LASKOSKI et al., 2014; LETTAT et al., 2010; REIS et al., 2014). Administering a concentrate to animals reduces the dietary fiber content, which decreases rumination and salivary buffering. These factors contribute to the increased risk of ruminal lactic acidosis (MINERVINO et al., 2014b).

The use of melons as a low cost alternative in animal feed has already been evaluated in sheep and cattle in animal production studies witch demonstrated the viability of this fruit as a partial replacement of energy-rich grains (LIMA et al., 2011, 2012). However, few studies report possible clinical changes of this supplementation. In sheep farming systems in the northeast region, we observed the 
use of this waste as an additional supplementation in approximately $20 \%-30 \%$ of the diet or at a higher level of $70 \%-80 \%$ of the diet when there is great availability of fruit or when there are food shortages due to drought (OLIVEIRA, 2013). Melon, which is rich in soluble carbohydrates, can induce ruminal lactic acidosis, particularly in nonadapted sheep. Thus, this study aimed to evaluate the effects of two diets with different amounts of melon on certain clinical variables when the diet was suddenly administered to nonadapted sheep.

\section{Materials and Methods}

This study was approved by the Ethics Committee on Animal Use of the Faculty of Veterinary Medicine and Animal Science of the University of São Paulo (São Paulo, Brazil; process number 2141/2011).

\section{Animals and feeding}

We used 12 male Santa Inês crossbred sheep that were fitted with a ruminal cannula. The average body weight was $25 \pm 3 \mathrm{~kg}$ and age was 8 months. The animals were kept in collective cages with free access to water and mineral salt (Ovinofós, Tortuga Animal Science Company, São Paulo, Brazil). They were fed a basal diet containing forage (hay; Cynodon dactylon (L) Pers; coast cross), which was offered based on $2.3 \%$ of the body weight. The sheep had never been previously fed with concentrates, melon pulp, or other fruits and roots. The sheep underwent a 30-day adjustment period to the facilities and feeding management. The sheep were dewormed with moxidectin, a broad-spectrum endectocide (Cydectin; Zoetis Animal Health, São Paulo, Brazil).

\section{Experimental design}

The animals were randomly divided into two similar groups of six animals each: the G25\% group received melon corresponding to $25 \% \mathrm{DM}$ of the diet, and the G75\% group 75\% DM of the diet. The rationale for only two groups with $25 \%$ and $75 \%$ of the melon diet was to simulate how this fruit is used by local farmers who routinely employ the fruit as additional supplementation of $20 \%-30 \%$ of the diet, or they employ the fruit as the main food source for sheep and goats in the dry season with ad libtum fruit offering for a dietary intake of $70 \%$ 80\% (OLIVEIRA, 2013). Physical examination was performed at the following times: baseline (T0; immediately before melon administration), and after starting supplement administration at 3 hours (T3 h), 6 hours (T6 h), 12 hours (T12 h), 18 hours (T18 h), and 24 hours (T24 h). At each time point immediately after the physical examination, ruminal fluid samples were obtained directly from the cannula for $\mathrm{pH}$ determination using a microprocessor $\mathrm{pH}$ meter (PG 1800 model; Gehaka, São Paulo, Brazil) that was previously calibrated in accordance with the manufacturer's instructions.

\section{Melon offering}

Fruit choice was determined by Brix $(\mathrm{Bx})$ degree using a digital refractometer (PR-101 model; Atago, São Paulo, Brazil) with scale of $0^{\circ} \mathrm{Bx}$ to $45^{\circ} \mathrm{Bx}$. Fruits that had at least $12^{\circ} \mathrm{Bx}$ were chosen. Chemical analysis was performed on the fruit in accordance with classical techniques (AOAC, 1992). For both groups, the melons averaged $12.5^{\circ} \pm 0.3^{\circ} \mathrm{Bx}, 7.3 \%$ $\pm 0.2 \%$ dry matter, $9.30 \% \pm 0.1 \%$ ash, $90.70 \%$ $\pm 0.3 \%$ organic matter, $11.58 \% \pm 0.33 \%$ crude protein, $7.62 \% \pm 0.25 \%$ ethereal extract, $20.58 \% \pm$ $0.2 \%$ neutral detergent fiber, $16.68 \% \pm 0.1 \%$ acid detergent fiber, $69.94 \% \pm 0.21 \%$ total carbohydrates, $49.36 \% \pm 0.15 \%$ nonfiber carbohydrates, and $5.86 \%$ $\pm 0.02 \%$ lignin. After crushing the full fruit without seeds in a conventional blender to give it a pasty content, the melon was administered intraruminally through the cannula. The total quantity of fruit was abruptly administered at a single time. To calculate the amount of content to administer, we used a dry matter intake that was $2.3 \%$ of the animal's live 
weight, which was obtained after it had fasted for 12 hours. Thus, a $25-\mathrm{kg}$ sheep received $1970 \mathrm{~g}$ and $5900 \mathrm{~g}$ of processed fruit in groups G25\% and G75\%, respectively.

\section{Physical examination}

During the animal physical examinations, we evaluated the heart rate and respiratory rate per minute, ruminal movements for 2 minutes, temperature, presence or absence of appetite, and any other clinical change that happened by chance, based on the recommendations described by Dirksen et al. (1993). To perform abdominal circumference measurements, we used a conventional metric tape at the seventh thoracic vertebra.

\section{Statistical analysis}

All data were initially tested for their distribution by the Kolmogorov-Smirnov test. The data were then analyzed by two-way repeated measures analysis of variance, followed by Bonferroni's comparison of the means test to evaluate the difference between the experimental groups and the different collection times. To study the relationships between the variables, we used a regression analysis with calculations of the determination factors and the Pearson correlation. The significance level adopted in this study was $5 \%$. The analyses were performed using statistical software (GraphPad Prisma; GraphPad Software Inc., La Jolla, CA, USA).

\section{Results}

Table 1 shows the average results and standard deviations in the heart and respiratory rate during the experiment, and the ruminal fluid $\mathrm{pH}$. In the $\mathrm{G} 75 \%$ group, we observed an increase in the heart rate from the baseline values for all evaluated periods, except for $\mathrm{T} 18 \mathrm{~h}(\mathrm{p}<0.05)$. At these times, the heart rate values were above the reference values for the species (i.e., 70-80 bpm) (PUGH, 2004). There was no significant difference between the two groups in heart rate at baseline and at $\mathrm{T} 12 \mathrm{~h}(\mathrm{p}>0.05)$; however, for the remaining times, the G75\% group had a higher number of beats per minute, compared to the $\mathrm{G} 25 \%$ group $(\mathrm{p}<0.05)$.

In the G75\% group, we observed an increased respiratory rate $(\mathrm{RR})$ at $\mathrm{T} 3 \mathrm{~h}$, compared to the other times, except for T18 h. At these two times, the sheep showed mean RR values that were greater than the physiological limits of the species (PUGH, 2004). The mean RR values were significantly greater in the $\mathrm{G} 75 \%$ animals than in the $\mathrm{G} 25 \%$ animals, except at $\mathrm{T} 3 \mathrm{~h}(\mathrm{p}<0.05)$.

In the intragroup analysis, smaller mean $\mathrm{pH}$ values were detected in the $\mathrm{G} 25 \%$ group at $\mathrm{T} 3 \mathrm{~h}$ and T6 h $(\mathrm{p}<0.05)$, and increased gradually until $\mathrm{T} 12 \mathrm{~h}$. From this point on, the original values were re-established. In the G75\% group, the ruminal fluid $\mathrm{pH}$ decreased starting at $\mathrm{T} 3 \mathrm{~h}$, and remained lower than the $\mathrm{T} 0$ value for all other time points $(\mathrm{p}<0.05)$. It reached values that were indicative of ruminal lactic acidosis. There was no significant difference between the two groups with regard to ruminal fluid $\mathrm{pH}$ up to $\mathrm{T} 3 \mathrm{~h}$; however, from this point until the end of the experiment the G75\% group showed a more acidic $\mathrm{pH}$, compared to the $\mathrm{G} 25 \%$ group $(\mathrm{p}<$ $0.0001)$.

Table 2 shows the mean and standard deviation of ruminal movement (RM), rectal temperature $\left({ }^{\circ} \mathrm{C}\right)$, and abdominal circumference of the sheep during the experiment. Within the G75\% group, a greater number of movements was detected at T0 and $\mathrm{T} 3 \mathrm{~h}$ than at T12 h., T18 h, and T24 h; the same trend was also observed at $\mathrm{T} 6 \mathrm{~h}$ in relation to $\mathrm{T} 24$ $\mathrm{h}(\mathrm{p}<0.05)$. There were no significant differences between the two groups regarding RM up to T6 $\mathrm{h}$ $(p>0.05)$. However, from $\mathrm{T} 12 \mathrm{~h}$ until the end of the experiment, the G75\% group had fewer RMs, compared to the G25\% group ( $<<0.05)$. 
Table 1. The mean value and standard deviation of heart rate (HR), respiratory rate (RR), and $\mathrm{pH}$ of the ruminal fluid from sheep fed a single administration (time 0 ) of melon in an amount corresponding to $25 \%$ or $75 \%$ of dry matter.

\begin{tabular}{ccccccc}
\hline \multirow{2}{*}{ Time $(\mathrm{h})$} & \multicolumn{2}{c}{$\mathrm{HR}(\mathrm{bpm})$} & \multicolumn{2}{c}{$\mathrm{RR}(\mathrm{breaths} / \mathrm{min})$} & \multicolumn{2}{c}{$\mathrm{pH}$ of the ruminal fluid } \\
\cline { 2 - 7 } & $\mathrm{G} 25 \%$ & $\mathrm{G} 75 \%$ & $\mathrm{G} 25 \%$ & $\mathrm{G} 75 \%$ & $\mathrm{G} 25 \%$ & $\mathrm{G} 75 \%$ \\
\hline 0 & $68^{\mathrm{Aa}} \pm 8.0$ & $77^{\mathrm{Ab}} \pm 12.0$ & $21^{\mathrm{Aa}} \pm 2.0$ & $21^{\mathrm{Ab}} \pm 4.2$ & $6.58^{\mathrm{Aa}} \pm 0.13$ & $6.33^{\mathrm{Aa}} \pm 0.33$ \\
3 & $74^{\mathrm{Ba}} \pm 3.8$ & $106^{\mathrm{Aa}} \pm 10.1$ & $20^{\mathrm{Aa}} \pm 1.8$ & $25^{\mathrm{Ba}} \pm 2.0$ & $5.52^{\mathrm{Ac}} \pm 0.13$ & $5.81^{\mathrm{Ab}} \pm 0.10$ \\
6 & $85^{\mathrm{Ba}} \pm 10.1$ & $113^{\mathrm{Aa}} \pm 16.6$ & $22^{\mathrm{Aa}} \pm 3.3$ & $20^{\mathrm{Ab}} \pm 0.5$ & $5.59^{\mathrm{Abc}} \pm 0.27$ & $4.98^{\mathrm{Bc}} \pm 0.22$ \\
12 & $80^{\mathrm{Aa}} \pm 4.7$ & $103^{\mathrm{Aa}} \pm 28.4$ & $20^{\mathrm{Aa}} \pm 2.4$ & $20^{\mathrm{Ab}} \pm 3.3$ & $5.86^{\mathrm{Ab}} \pm 0.15$ & $4.45^{\mathrm{Bd}} \pm 0.23$ \\
18 & $76^{\mathrm{Ba}} \pm 12.1$ & $102^{\mathrm{Aab}} \pm 15.9$ & $21^{\mathrm{Aa}} \pm 2.5$ & $22^{\mathrm{Aab}} \pm 6.0$ & $6.33^{\mathrm{Aa}} \pm 0.24$ & $4.35^{\mathrm{Bd}} \pm 0.12$ \\
24 & $73^{\mathrm{Ba}} \pm 14.4$ & $112^{\mathrm{Aa}} \pm 22.3$ & $21^{\mathrm{Aa}} \pm 4.1$ & $18^{\mathrm{Ab}} \pm 3.7$ & $6.4^{\mathrm{Aa}} \pm 0.19$ & $4.41^{\mathrm{Bd}} \pm 0.19$ \\
\hline
\end{tabular}

Different capital letters in the same row indicate a statistical difference of the variable between the experimental groups. Different lowercase letters in the same column indicate a statistical difference between the different times within the same group $(\mathrm{p}<0.05)$.

Table 2. The mean values and standard deviations of ruminal movement (RM), temperature, and abdominal circumference of sheep fed with a single administration (time 0 ) of melon in an amount corresponding to $25 \%$ and $75 \%$ of dry matter.

\begin{tabular}{ccccccc}
\hline \multirow{2}{*}{ Time $(\mathrm{h})$} & \multicolumn{2}{c}{$\mathrm{RM}(2 \mathrm{~min})$} & \multicolumn{2}{c}{ Temperature $\left({ }^{\circ} \mathrm{C}\right)$} & \multicolumn{2}{c}{ Abdominal circumference $(\mathrm{cm})$} \\
\cline { 2 - 7 } & $\mathrm{G} 25 \%$ & $\mathrm{G} 75 \%$ & $\mathrm{G} 25 \%$ & $\mathrm{G} 75 \%$ & $\mathrm{G} 25 \%$ & $\mathrm{G} 75 \%$ \\
\hline 0 & $3.0^{\mathrm{Aa}} \pm 0.9$ & $2.5^{\mathrm{Aa}} \pm 0.5$ & $38.5^{\mathrm{Aa}} \pm 0.43$ & $39.0^{\mathrm{Aa}} \pm 0.99$ & $95.7^{\mathrm{Bb}} \pm 1.21$ & $98.3^{\mathrm{Ab}} \pm 2.0$ \\
3 & $2.8^{\mathrm{Aa}} \pm 0.4$ & $3.2^{\mathrm{Aa}} \pm 1.6$ & $38.9^{\mathrm{Aa}} \pm 0.39$ & $39.0^{\mathrm{Aa}} \pm 0.73$ & $99.3^{\mathrm{Ba}} \pm 1.50$ & $109.0^{\mathrm{Aa}} \pm 2.0$ \\
6 & $2.0^{\mathrm{Aa}} \pm 0.6$ & $1.8^{\mathrm{Aab}} \pm 0.4$ & $39.2^{\mathrm{Aa}} \pm 0.20$ & $39.7^{\mathrm{Aa}} \pm 0.33$ & - & - \\
12 & $2.3^{\mathrm{Aa}} \pm 0.5$ & $1.0^{\mathrm{Bbc}} \pm 0.6$ & $38.5^{\mathrm{Aa}} \pm 0.46$ & $39.5^{\mathrm{Aa}} \pm 0.50$ & - & - \\
18 & $2.2^{\mathrm{Aa}} \pm 0.4$ & $0.8^{\mathrm{Bbc}} \pm 0.7$ & $38.1^{\mathrm{Aa}} \pm 0.52$ & $38.7^{\mathrm{Aa}} \pm 1.08$ & - & - \\
24 & $2.3^{\mathrm{Aa}} \pm 0.5$ & $0.5^{\mathrm{Bc}} \pm 0.5$ & $38.5^{\mathrm{Aa}} \pm 0.86$ & $39.0^{\mathrm{Aa}} \pm 0.82$ & - & - \\
\hline
\end{tabular}

Different capital letters in the same row indicate a statistical difference between the groups. Different lowercase letters in the same column indicate a statistical difference between times within the same group $(\mathrm{p}<0.05)$.

In the intergroup analysis and in the intragroup analysis, there were no significant differences in rectal temperature between the two studied groups at each of the assessed times $(\mathrm{p}>0.05)$.

The abdominal circumference in the G25\% group was $95.7 \pm 1.21 \mathrm{~cm}$ at $\mathrm{T} 0$ and $99.3 \pm 1.5 \mathrm{~cm}$ at $\mathrm{T} 3 \mathrm{~h}$ with no significant difference between the two times. However, the G75\% group had a mean abdominal circumference of $98.3 \pm 2.0 \mathrm{~cm}$ at $\mathrm{T} 0$ and $109.0 \pm 2.0 \mathrm{~cm}$ at T3 h. These values were significantly different from the $\mathrm{T} 0 \mathrm{~h}$ and $\mathrm{T} 3 \mathrm{~h}$ values in the $\mathrm{G} 25 \%$ group.

All clinical events that where observed during the course of the test are shown in Table 3. No clinical events were observed in the G25\% group. However, in the G75\% group, two animals had diarrhea, fasciculations, and bruxism during the experiment. Significant depression was observed in $50 \%$ of animals, and intense diuresis was observed in all animals of this group.

By evaluating only the data of times T0 and $\mathrm{T} 3 \mathrm{~h}$ in the two experimental groups, there was a positive linear correlation between the abdominal circumference and the heart rate $\left(r^{2}=0.8378\right)$. By evaluating only T0 and T3 h in the G75\% group, a positive polynomial correlation was observed between the abdominal circumference and the respiratory rate in the sheep of this group $\left(r^{2}=0.6884\right)$.

Sheep appetite was fully re-established after the end of the 24-hour experiment in animals of the G25\% group. However, at this time point in the G75\% group, the food intake was very small and the animals had a capricious appetite. It normalized only after 4-5 days on average. 
Table 3. Clinical events in the animals during the trial.

\begin{tabular}{ccc}
\hline Clinical occurrence & $\begin{array}{c}\text { G25\% } \\
\text { (N of affected animals/ Total N of } \\
\text { animals) }\end{array}$ & $\begin{array}{c}\text { G75\% } \\
\text { (N of affected animals/ Total N of } \\
\text { animals) }\end{array}$ \\
\hline Diarrhea & $0 / 6$ & $2 / 6$ \\
Depression & $0 / 6$ & $3 / 6$ \\
Fasciculations & $0 / 6$ & $2 / 6$ \\
Bruxism & $0 / 6$ & $2 / 6$ \\
Kyphosis & $0 / 6$ & $3 / 6$ \\
Dehydration & $0 / 6$ & $0 / 6$ \\
Intense diuresis & $0 / 6$ & $6 / 6$ \\
\hline
\end{tabular}

\section{Discussion}

Based on the $\mathrm{pH}$ of the ruminal fluid and according to the classification ruminal acidosis (REIS et al., 2014), it can be assumed that the G25\% sheep had subacute ruminal acidosis for 6 hours after the melon offer, which was caused by excess chain fatty acids (SCFA). However, this change did not produce any obvious clinical symptoms in the sheep. In the G75\% group, all sheep had the typical clinical picture of acute ruminal lactic acidosis with a ruminal fluid $\mathrm{pH}$ less than 5.0 from $\mathrm{T} 6 \mathrm{~h}$ until the end of the study. Despite the clinical picture, none of the sheep became dehydrated, which is a frequent change in this disease (ORTOLANI et al., 2010; RODRIGUES et al., 2011; VIEIRA et al., 2006); however, they had intense, temporary diuresis.

Immediately after the administration of large amounts of melon by ruminal cannula, the G75\% group had a striking increase in the abdominal volume, predominantly in the ventral left. This increase in the circumference remained evident for the first three hours; however, after T3 h no abdominal enlargement was observed. Hungate (1966) reports that the more fluid the ruminal content has, the greater the output rate of ruminal exit (i.e., turnover) to the omasum. Because the melon used in the experiment contained $92.72 \%$ wet matter, it was normal that the increased turnover rate to the omasum occurred.

In the present study, no dehydration occurred in the animals. The probable cause of tachycardia observed in of the G75\% sheep was the increase in abdominal volume (Figure 1). Dougherty (1940) infused gas in sheep rumen to cause an intraruminal increase in pressure, which then caused tachycardia; he correlated this factor with an increase in blood pressure. In the same study, the author found an increase in the RR (as we found at $\mathrm{T} 3 \mathrm{~h}$ in the $\mathrm{G} 75 \%$ group), but found no change in RMs. Similar to what happened concerning the influence of increased abdominal circumference on heart rate, this increased abdominal circumference also affect the respiratory rate (Figure 2). Increasing the pressure in the rumen increases the respiratory rate by decreasing the lung capacity (RADOSTITS et al., 2007). Therefore, tachycardia and tachypnea after the third hour of induction resulted from increased abdominal circumference and increased pressure on the chest after the administration of melon by the cannula, and not from dehydration as in classic cases of ARLA (ORTOLANI et al., 2010; RODRIGUES et al., 2011). 
Figure 1. The relationship between the sheep abdominal circumference $(\mathrm{cm})$ and the heart rate $(\mathrm{bpm})$ at $\mathrm{T} 0$ and $\mathrm{T} 3$ (i.e., $3 \mathrm{~h}$ ) in the two experimental groups.

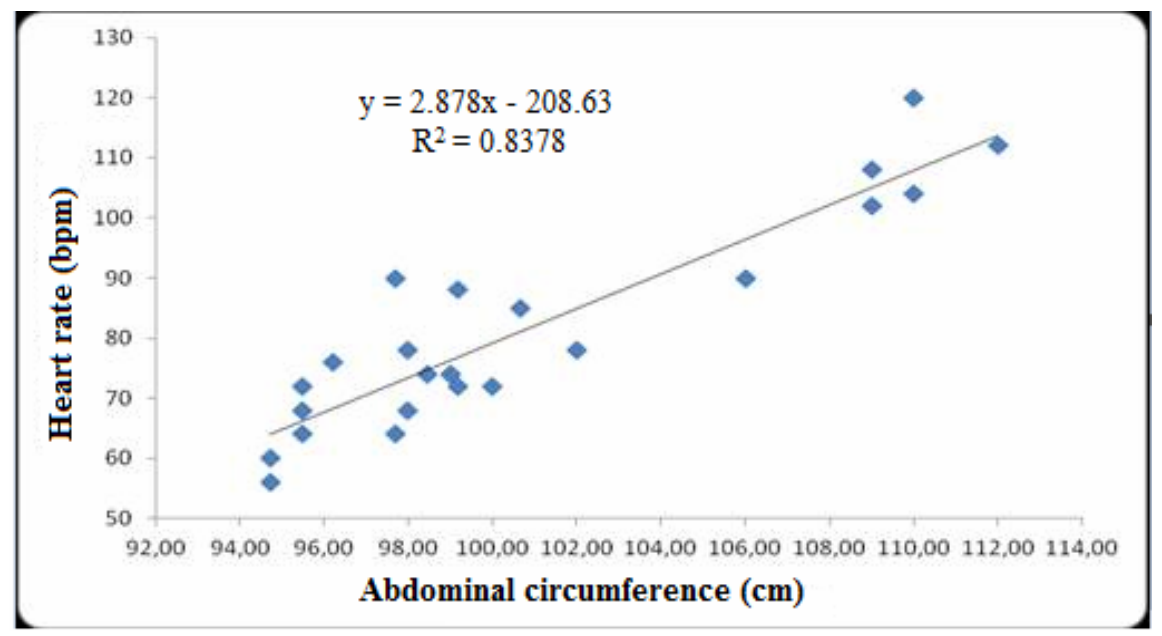

Figure 2. The relationship between the sheep abdominal circumference $(\mathrm{cm})$ and the respiratory rate (breaths/min) at T0 and T3 (i.e., $3 \mathrm{~h}$ after administering the melon) in the G75\% group during the experiment.

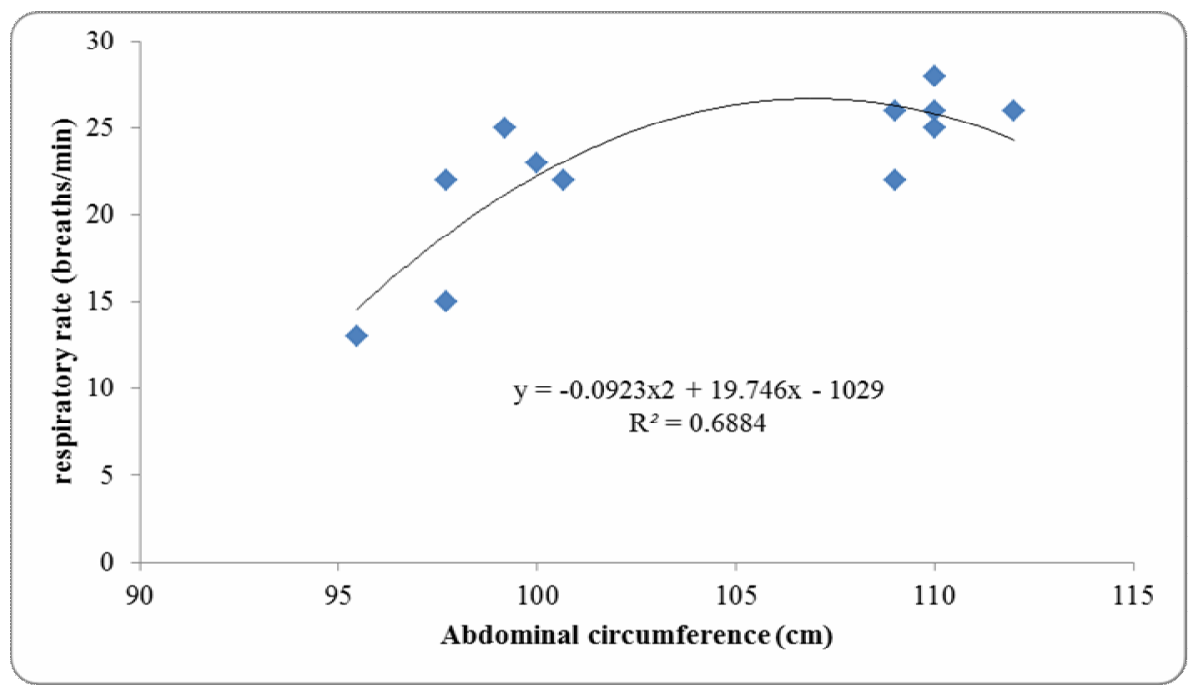

The RMs did not change in the G25\% group; however, RMs in the G75\% group was different from $\mathrm{T} 12 \mathrm{~h}$ to $\mathrm{T} 24 \mathrm{~h}(\mathrm{p}<0.05)$. In this group, at $\mathrm{T} 24 \mathrm{~h} 50 \%$ of the animals showed rumen stasis, which is an expected symptom in ARLA, especially when the ruminal $\mathrm{pH}$ values are lower than 5.0 (BARRÊTO JÚNIOR et al., 2008). One-half of the G75\% sheep showed no rumen atony, a fact that can be atypical: the cessation of RMs is a physiological defense because it reduces the absorption of acids by the mucosa (WILLIAMS; MACKENZIE, 1965).
However, a similar condition has previously been observed in cattle (ORTOLANI et al., 2010).

Rumen changes resulting from sudden melon intake in the amount of $25 \%$ were not substantially sufficient to cause clear clinical signs. In field conditions, this amount of melon would be even safer because the animal would ingest the food and later chew it. In this situation, there would be a buffering of the ruminal contents by the saliva (MINERVINO et al., 2014b). This action did not 
occur in the experiment because the fruit was crushed and administered through a ruminal cannula.

We note that, even with considerable increase in abdominal circumference in the G75\% sheep, there was no change in RMs at T3 h. Radostits et al. (2007) stated that simply increasing the ruminal volume does not produce changes in belching and organ contraction. Smith (2014) reports that, up to a certain degree of rumen dilatation, RMs increase in frequency because the gastric centers are stimulated by afferent excitatory impulses. Above a certain expansion limit, the effect is reversed and cause ruminal hypomotility, and finally atony. In the studied sheep, abdominal swelling was not intense and sufficiently prolonged to cause ruminal atony in the animals. As may be expected, the rectal temperature did not change in any of the animals during the experiment. The same result occurred in cattle with ARLA (ORTOLANI et al., 2010).

\section{Conclusion}

The results show that offering high amounts of melon $(75 \% \mathrm{DM})$ is not recommended. However, an intake of $25 \% \mathrm{DM}$ does not cause clinical changes in the sheep, even when they suddenly receive the energy supplement. Because of the low cost and production gain already described in the literature, this fruit is an option for food supplementation in sheep.

\section{Acknowledgement}

This research was funded by the São Paulo State Research Support Foundation (São Paulo, Brazil).

\section{References}

ASSOCIATION OF OFFICIAL ANALYTICAL CHEMISTS - AOAC. Official methods of analysis of the Association of the Agricultural Chemists. $12^{\text {th }}$ ed. Washington: AOAC, 1992. $1141 \mathrm{p}$.
BARRÊTO JÚNIOR, R. A.; MINERVINO, A. H. H.; RODRIGUES, F. A. M. L.; ANTONELLI, A. C.; MORI, C. S.; SUCUPIRA, M. C. A.; ORTOLANI, E. L. Avaliação do potencial da polpa cítrica em provocar acidose láctica ruminal aguda em bovinos. Brazilian Journal of Veterinary Research and Animal Science, São Paulo, v. 45, n. 6, p. 421-428, 2008.

BRAUN, U.; RIHS, T.; SCHEFER, U. Ruminal lactic acidosis in sheep and goats. Veterinary Record, Londres, v. 130, n. 16, p. 343-349, 1992.

DIRKSEN, G.; GRÜNDER, H. D.; STÖBER, M. Rosenberger - exame clínico dos bovinos. 3. ed. Rio de Janeiro: Guanabara Koogan: Rio de Janeiro, 1993. 419 p.

DOUGHERTY, R. W. Physiological studies of induced and natural bloat in dairy cattle. Journal of the American Veterinary Medical Association, Schaumburg, v. 96, n. 1, p. 43-46, 1940.

HUNGATE, R. E. The rumen and its microbes. New York: Academic Press, 1966. 533 p.

LASKOSKI, L. M.; MURARO, L. S.; SANTANA JÚNIOR, M. S.; CARVALHO, M. B.; FREITAS, S. H.; DÓRIA, R. G. S.; SANTOS, M. D.; DITTRICH, R. L. Sodium bicarbonate as prevention of metabolic acidosis in sheep submitted to experimental ruminal acidosis. Pesquisa Veterinária Brasileira, Rio de Janeiro, v. 34, n. 9, p. 822-826, 2014.

LETTAT, A.; NOZIÈRE, P.; SILBERBERG, M.; MORGAVI, D. P.; BERGER, C.; MART, C. Experimental feed induction of ruminal lactic, propionic, or butyric acidosis in sheep. Journal of Animal Science, Champaign, v. 88 , n. 9, p. 3041-3046, 2010.

LIMA, C. A. C.; LIMA, G. F. C.; COSTA, R. G.; MEDEIROS, A. N.; AGUIAR, E. M.; JÚNIORS, V. L. Efeito de níveis de melão em substituição ao milho moído sobre o desempenho, o consumo e a digestibilidade dos nutrientes em ovinos Morada Nova. Revista Brasileira de Zootecnia, Viçosa, MG, v. 41, n. 1, p. 164-171, 2012.

LIMA, G. F. C.; SILVA, J. G. M.; AGUIAR, E. M.; FERREIRA, M. A.; RANGEL, A. H. N.; TORRES, J. F. Frutos-refugo de melão em substituição ao farelo de trigo na alimentação de vacas leiteiras. Revista Caatinga, Mossoró, v. 24, n. 3, p. 190-197, 2011.

LOUSADA JÚNIOR, J. E.; NEIVA, J. N. M.; RODRIGUEZ, N. M.; PIMENTEL, J. C. M.; LÔBO, R. N. B. Consumo e digestibilidade de subprodutos do processamento de frutas em ovinos. Revista Brasileira de Zootecnia, Viçosa, MG, v. 34, n. 2, p. 659-669, 2005. 
MINERVINO, A. H. H.; ARAÚJO, C. A. S. C.; KAMINISHIKAWAHARA, C. M.; SOARES, F. B.; RODRIGUES, F. A. M. L.; REIS, L. F.; OLIVEIRA, F. L. C.; BARRÊTO JÚNIOR, R. A.; MORI, C. S.; ORTOLANI, E. L. Influência de diferentes dietas com alto teor de concentrados sobre parâmetros ruminais, bioquímicos e urinários de ovinos. Brazilian Journal Veterinary Research and Animal Science, São Paulo, v. 51, n. 1, p. 30-36, 2014a.

MINERVINO, A. H. H.; KAMINISHIKAWAHARA, C. M.; SOARES, F. B.; ARAUJO, C. A. S. C.; REIS, L. F.; VECHIATO, T. A. F.; FERREIRA, R. N. F.; BARRÊTO JÚNIOR, R. A.; MORI, C. S.; ORTOLANI, E. L. Behaviour of confined sheep fed with different concentrate sources. Arquivo Brasileiro de Medicina Veterinária e Zootecnia, Belo Horizonte, v. 66, n. 4, p. 1163-1170, 2014b.

NAGARAJA, T. G.; LECHTENBERG, K. F. Acidosis in feedlot cattle. Veterinary Clinics of North America: Food Animal Practice, Amsterdam, v. 23, n. 2, p. 333350, 2007.

OLIVEIRA, F. L. C. Avaliação da ingestão súbita de melão com alto teor de açúcar sobre a saúde ruminal em ovinos não adaptados. 2013. Dissertação (Mestrado em Medicina Veterinária) - Universidade de São Paulo, São Paulo.

ORTOLANI, E. L.; LEAL, M. L. R.; MINERVINO, A. H. H.; AIRES, A. R.; COOP, R.; JACKSON, F.; SUTTLE, N. F. Effects of parasitism on cellular immune response in sheep experimentally infected with Haemonchus contortus. Veterinary Parasitology, Amsterdam, v. 196, n. 2, p. 230-234, 2013.

ORTOLANI, E. L.; MARUTA, C. A.; MINERVINO, A. H. H. Aspectos clínicos da indução experimental de acidose láctica ruminal em zebuínos e taurinos. Brazilian Journal of Veterinary Research and Animal Science, São Paulo, v. 47, n. 4, p. 253-261, 2010.

PUGH, D. G. Clínica de ovinos e caprinos. São Paulo: Roca, 2004. 528 p.
RADOSTITS, O. M.; GAY, C. C.; HINCHCLIFF, K. $\mathrm{W}$.; CONSTABLE, P. D. Veterinary medicine. $10^{\text {th }}$ ed. London: Elsevier Saunders, London, 2007. 2156 p.

REIS, L. F.; MINERVINO, A. H. H.; ARAÚJO, C. A.; SOUSA, R. S.; OLIVEIRA, F. L.; RODRIGUES, F. A.; MEIRA JÚNIOR, E. B.; BARRÊTO JÚNIOR, R. A.; MORI, C. S.; ORTOLANI, E. L. Comparison of rumen fluid $\mathrm{pH}$ by continuous telemetry system and bench $\mathrm{pH}$ meter in sheep with different ranges of ruminal $\mathrm{pH}$. The Scientific World Journal, Cairo, Article ID 195782, p. 1-4, 2014.

RODRIGUES, F. A. M. L.; MINERVINO, A. H. H.; BARRÊTO JÚNIOR, R. A.; ANTONELLI, A. C.; REIS, L. F.; ARAÚJO, C. A. S. C.; FERREIRA, R. N. F.; VECHIATO, T. A. F.; MORI, C. S.; ORTOLANI, E. L. Avaliação clínica do uso de solução salina hipertônica no tratamento da acidose láctica ruminal aguda em bovinos. Brazilian Journal of Veterinary Research and Animal Science, São Paulo, v. 48, n. 6, p. 446-453, 2011.

RODRIGUES,M.M.;NEIVA,J.N.M.;VASCONCELOS, V. R.; LÔBO, R. N. B.; PIMENTEL, J. C. M.; MOURA, A. A. A. N. Utilização do farelo de castanha de caju na terminação de ovinos em confinamento. Revista Brasileira de Zootecnia, Viçosa, MG, v. 32, n. 1, p. 240248, 2003.

SMITH, B. P. Large animal internal medicine. $5^{\text {th }}$ ed. St. Louis: Mosby, 2014. 1712 p.

VIEIRA, A. C. S.; AFONSO, J. A. B.; MENDONÇA, C. L.; COSTA, N. A.; SOUZA, M. I. Estudo retrospectivo da acidose láctica em caprinos e ovinos atendidos na Clínica de Bovinos, Campus Garanhuns/UFRPE. Revista Brasileira de Ciências Agrárias, Recife, v. 1, n. 1, p. $97-$ 101, 2006.

WILLIAMS, V. J.; MACKENZIE, D. D. S. The absorption of lactic acid from the reticulo-rumen of the sheep. Australian Journal of Biological Sciences, Clayton, v. 18, n. 4, p. 917-934, 1965. 
